\title{
Simultaneous Organic Solids Disintegration and Fermentative Hydrogen Production by Pretreated Sludge Generated from Wastewater Treatment Plant
}

\author{
Mijung Kim, Sechang Oh, Randeep Rakwal, Chunguang Liu, and Zhenya Zhang
}

\begin{abstract}
This study examines fermentative hydrogen production from untreated (raw) sludge and pretreated sludge by sterilization treatment $(15,30,45$, and $60 \mathrm{~min})$ as substrate using mixed cultures in batch experiments under anaerobic thermophilic conditions. Longer treatment time was found to be highly effective for hydrolyzing organic matters in the sludge. Soluble chemical oxygen demand (SCOD) of pretreated sludge was 1.2 to 1.9-fold higher than that of untreated sludge. Sterilization treatment was found to accelerate and increase hydrogen production throughout the batch mode, but with no measurable methane production. Pretreated $(30 \mathrm{~min})$ sludge presented an optimal condition, resulting in maximum hydrogen yield $\left(25.1 \mathrm{ml} \mathrm{H}_{2} / \mathrm{g}-\mathrm{VS}\right)$ and the highest hydrogen content $(60.0 \%)$. Under the same conditions, enhanced hydrogen yield was 6.4-fold higher, which came with an additional benefit of efficient VS removal over the use of untreated sludge. This was attributed to destruction of solids in sludge during the solubilization process. Present findings have potential practical use in not only processes for efficient hydrogen production via anaerobic fermentation but also in waste treatment.
\end{abstract}

Index Terms-Sewage sludge, sterilization treatment, hydrogen production, mixed cultures, anaerobic fermentation.

\section{INTRODUCTION}

Worldwide, huge amounts of sewage sludge are discharged yearly. The sludge's are the organic waste generated from various stages of wastewater treatment plant. This also translates to a high cost requirement for disposal of sewage sludge and reuse in reclaimed land or for making concrete. Therefore, it is very important that we search for potential energy saving approaches by utilizing sewage sludge prior to waste disposal for a sustainable future environmentally friendly society [1]. Sewage sludge is composed of $95 \%$ water and $1-5 \%$ solids. The solid part contains a diverse population of microbes, organic matter, nutrients (nitrogen and phosphorus), and trace elements [2]. Based on these characteristics, the sludge can be used as inoculum and substrate for producing biogas (methane) through anaerobic digestion - a most commonly used process

Manuscript received June 9, 2013; revised August 18, 2013.

Mijung Kim, Randeep Rakwal, Chunguang Liu, and Zhenya Zhang are with the Graduate School of Life and Environmental Sciences, University of Tsukuba, Tsukuba, Ibaraki 305-8572, Japan.

Sechang Oh is with the Rice University, Houston, TX 77005 USA. He is now with the Graduate School of Comprehensive Human Science, University of Tsukuba, Tsukuba, Ibaraki 305-8574, Japan.

Randeep Rakwal is also with the Organization for Educational Initiatives, University of Tsukuba, Tsukuba, Ibaraki 305-8577, Japan.

Mijung Kim now is with National Institute of Advanced Industrial Science \& Technology (AIST), Tsukuba, Ibaraki 305-8562, Japan (e-mail: mijungkim1003@gmail.com; mijung-kimu@aist.go.jp). for sludge stabilization [1], [3].

Anaerobic digestion is widely used for sludge stabilization, as well as methane production using anaerobic microorganisms [4]. Despite the above benefits, a long sludge retention time is required for reducing the organic matter and producing methane by anaerobic digestion. Even after long periods (30-60 days) of digestion, the sludge degradation rate is low, due to presence of refractory materials that are hard to break during the anaerobic digestion period [5]. To counteract this disadvantage, several pretreatment methods, namely acid [6] alkali [7], thermal [8], ultrasonic [9], and microwave [10] have been proposed for dissolving organic solids in sewage sludge prior to anaerobic digestion. Eskicioglu et al. [11] reported an 31\% increase in methane production from microwave pretreated sewage sludge. Li et al. [5] demonstrated alkaline pretreatment of sewage sludge prior to anaerobic digestion substantially increased the degradation rate of organic substances with the help of $\mathrm{NaOH}$ hydrolysis, and which resulted in a significant increase in the production of methane.

In the $21^{\text {st }}$ century, biological hydrogen has attracted attention as a biofuel for the future. This is because hydrogen - a clean energy - can be directly used in fuel cells to generate electricity [1], [12]. Furthermore, hydrogen - an intermediary metabolite of anaerobic fermentation - is produced independently during the anaerobic digestion process [13]. Nevertheless, fermentative hydrogen production from sewage sludge has not been well investigated, primarily due to natural characteristics of low biodegradability that results in lower hydrogen yield [14]. Previous researches have reported improvement in fermentative hydrogen production by heat or sterilization methods. For example, Massanet-Nicolau et al. [3] found that pretreatment of sewage sludge by heat $\left(70^{\circ} \mathrm{C}\right)$ and enzyme prior to fermentation significantly boosted the hydrogen yield. Xiao and Liu [15] demonstrated sewage sludge sterilization at $121^{\circ} \mathrm{C}$ consistently improved hydrogen production; hydrogen consumption still occurred in anaerobic self-fermentation of imperfectly sterilized sludge due to existence of other hydrogen-consuming bacteria.

With these backgrounds, a sterilization pretreatment step was added to the sewage sludge in this study in order to establish an effective method for sludge solubilization. The main aim of this study was to assess the feasibility of hydrogen production from pretreated sludge as a substrate by mixed cultures including hydrogen-producing bacteria, without $\mathrm{pH}$ control and additional nutrients under anaerobic thermophilic conditions, in order to i) determine the effects of various sterilization times on sewage sludge for organic solids disintegration and microbial activity, ii) compare the 
effects of untreated sludge and pretreated sludge by sterilization treatment for fermentative hydrogen production, and iii) investigate the changes in $\mathrm{pH}$, soluble chemical oxygen demand (SCOD) including metabolites, carbohydrates, and ammonia nitrogen $\left(\mathrm{NH}_{4}^{+}-\mathrm{N}\right)$ as well as the volatile solids (VS) removal during the hydrogen fermentation process.

\section{MATERIALS AND METHODS}

\section{A. Raw Materials}

The substrate sewage sludge was obtained from a gravity sludge thickener line at the wastewater treatment plant in Ibaraki prefecture (Japan), and was stored at $4^{\circ} \mathrm{C}$. The $\mathrm{pH}$, alkalinity as $\mathrm{CaCO}_{3}$, and volatile suspended solids (VSS) of the sewage sludge were $6.4,4.8 \mathrm{~g} / 1$, and $7.4 \mathrm{~g} / \mathrm{l}$. Anaerobic digester sludge was also taken from the wastewater treatment plant, and was used as seed sludge. The total solids (TS), VS, and $\mathrm{pH}$ of the digested sludge were $0.8 \%, 0.5 \%$, and 7.2.

\section{B. Preparation of Hydrogen Producing Inocula}

Hydrogen producing inocula were cultivated in a $250-\mathrm{ml}$ of anaerobic bottle (SIBATA, Tokyo, Japan) using digested sludge as the original source of microorganisms and glucose medium was used as the substrate [16]. In order to inactivate hydrogen-utilizing bacteria and harvest hydrogen-producing bacteria, the digested sludge was heat treated at $100^{\circ} \mathrm{C}$ for 15 min [17]. The $200 \mathrm{ml}$ of heat-treated sludge was mixed with glucose $(8250 \mathrm{mg} / \mathrm{l})$ containing medium, and cultured at $55^{\circ} \mathrm{C}$ for 24 hours [16]. The medium contained 11 inorganic supplements $\quad(\mathrm{mg} / \mathrm{l}): \quad \mathrm{NH}_{4} \mathrm{Cl} \quad 1300, \mathrm{KH}_{2} \mathrm{PO}_{4} \quad 250$, $\mathrm{MgCl}_{2} \cdot 6 \mathrm{H}_{2} \mathrm{O} 125, \mathrm{FeSO}_{4} \cdot 7 \mathrm{H}_{2} \mathrm{O} 5, \mathrm{ZnCl}_{2} 0.5, \mathrm{NiCl}_{2} \cdot 6 \mathrm{H}_{2} \mathrm{O}$ $0.5, \mathrm{H}_{3} \mathrm{BO}_{4} 0.5, \mathrm{NaMoO}_{4} \cdot 2 \mathrm{H}_{2} \mathrm{O} 0.5, \mathrm{MnCl}_{2} \cdot 6 \mathrm{H}_{2} \mathrm{O} 2.5, \mathrm{KI}$ 2.5, and $\mathrm{CoCl}_{2} \cdot 6 \mathrm{H}_{2} \mathrm{O}$ 2.5. The mixed culture showed high glucose degradation efficiency of $92.4 \%$ and over $50.0 \%$ of hydrogen content in the produced biogas, but without any detectable methane. This concoction was used as the mixed cultures for batch experiments.

\section{Pretreatment Experiments}

Sewage sludge was pretreated by sterilization treatment in an autoclave. The sewage sludge was sterilized for $15 \mathrm{~min}, 30$ $\min , 45 \mathrm{~min}$, or $60 \mathrm{~min}$ at a temperature of $121^{\circ} \mathrm{C}$ and pressure of $1.2 \mathrm{~atm}$, followed by its use as a substrate for fermentative hydrogen production for determining the optimal sterilization time. The effects of five factors, i.e. soluble carbohydrate (SC), $\mathrm{NH}_{4}{ }^{+}-\mathrm{N}, \mathrm{SCOD}$, disintegration rate of organic matter, and ATP value from the sterilization sludge were estimated to determine solubilization rates of organic solids in the sludge. The optimal condition for four different kinds of sludge pretreatment time was assessed according to maximum hydrogen yield at each time point.

\section{Fermentative Hydrogen Production from Untreated or Pretreated Sludge}

Batch experiments were performed in 250-ml anaerobic bottles (SIBATA, Tokyo, Japan). The substrate to produce hydrogen was pretreated sludge by sterilization treatment. All reactors were filled with $135 \mathrm{ml}$ of untreated or pretreated sludge and $15 \mathrm{ml}$ of mixed cultures to obtain a working volume of $150 \mathrm{ml}$. Fermentation of only mixed cultures was used as the control. The initial $\mathrm{pH}$ was adjusted to 7.0 with $4 \mathrm{~N} \mathrm{NaOH}$ and $4 \mathrm{~N} \mathrm{HCl}$ during the hydrogen fermentation process. Rubber stoppers were used to seal the reactors, and the air was purged with $\mathrm{N}_{2}$ to produce anaerobic conditions. The batch experiments were performed at $55^{\circ} \mathrm{C}$ for three days without any $\mathrm{pH}$ control. Performance indicators measured were - volatile fatty acids (VFAs) content, $\mathrm{NH}_{4}^{+}-\mathrm{N}, \mathrm{SC}$, $\mathrm{SCOD}$, and $\mathrm{pH}$ as well as the biogas concentration and composition. All reactor experiments were carried out in triplicate and the average values are presented.

\section{E. Analytical Methods}

Chemical oxygen demand (COD), SCOD, TS, and VS were measured in accordance with the standard methods [18]. Carbohydrate concentration was estimated by the phenol-sulfuric acid method with glucose as a standard solution [19]. The $\mathrm{pH}$ value was measured using a SevenGo proTM pH/Ion meter (SG8, METTLER TOLEDO). Concentration of $\mathrm{NH}_{4}{ }^{+}-\mathrm{N}$ was determined using an ion meter (TiN-9001, Toyo Chemical Laboratories Co., Ltd., Tokyo, Japan). The concentrations of metabolites such as acetate, propionate, and butyrate were analyzed by HPLC (JASCO Co., Japan) equipped with a UV/VIS and a COSMOGEL 5C18-AR-II Packed Column $(4.6 \times 250 \mathrm{~mm})$ at $40^{\circ} \mathrm{C}$ using $20 \mathrm{mM}$ phosphate buffer $(\mathrm{pH} 2.5)$ as the mobile phase. The sample was centrifuged at 10,000 rpm for $10 \mathrm{~min}$, after which the supernatant was filtered using a $0.45 \mu \mathrm{m}$ membrane, and the filtrate was immediately analyzed at a flow rate of 1.0 $\mathrm{ml} / \mathrm{min}$. The ATP concentration was measured using a Bac Titer-Glo ${ }^{\text {TM }}$ Microbial Cell Viability Assay (Promega, USA). The composition of the biogas, including hydrogen, methane, and carbon dioxide, was determined by gas chromatography (GC-8A, SHIMADZU, Japan) using a thermal conductivity detector $\left(\mathrm{TCD}, 80^{\circ} \mathrm{C}\right)$ and a Porapak Q column $\left(60^{\circ} \mathrm{C}\right)$ with nitrogen as the carrier gas. Biogas was collected in $50-\mathrm{ml}$ plastic syringes, and volumes were directly read by the scale on the syringes. The effect of amount of each feedstock added was evaluated based on gas contents of the gas produced. The hydrogen yield was calculated as follows:

$$
Y_{H_{2}}=\left(V_{1}-V_{2}\right) / M
$$

where $Y_{H_{2}}\left(\mathrm{ml} / \mathrm{g}\right.$-VS sludge added) is the hydrogen yield; $V_{I}$ $(\mathrm{ml})$ is the cumulative hydrogen production from sludge samples during fermentation period; $V_{2}(\mathrm{ml})$ is the cumulative hydrogen production from control during fermentation period; $M(\mathrm{~g})$ is the VS (sludge) added. The VS removal efficiency was calculated by weight loss of VS values at the end of the hydrogen fermentation, relative to the starting content.

\section{RESULTS AND DISCUSSION}

\section{A. Characteristics of the Untreated or Pretreated Sludge}

Physicochemical characteristics of the untreated (raw) sludge and pretreated sludge's by sterilization treatment were analyzed before being used in hydrogen fermentation experiments. Results for the untreated sludge and pretreated sludge's are shown in Table I. The untreated sludge contained $2.01 \% \quad \mathrm{TS}, \quad 1.59 \% \quad \mathrm{VS}, 3341 \quad \mathrm{mg} / \mathrm{l}$ total carbohydrate (TC), $59 \mathrm{mg} / 1 \mathrm{SC}, 12715 \mathrm{mg} / 1$ total chemical 
oxygen demand (TCOD), and $1725 \mathrm{mg} / \mathrm{l}$ SCOD. In all pretreated sludge's, TS and VS of the sludge decreased with increasing sterilization times, relative to initial content of TS and VS in the untreated sludge. Pretreated sludge for $60 \mathrm{~min}$ showed the highest disintegration rate of $21.9 \%$ (TS) and $23.9 \%$ (VS), followed by the pretreated sludge for $45 \mathrm{~min}$ of $19.9 \%$ (TS) and $22.0 \%$ (VS). TS and VS of the pretreated sludge for $30 \mathrm{~min}$ were disintegrated by $19.4 \%$ and $21.4 \%$, respectively. For the pretreated sludge for $15 \mathrm{~min}$, the disintegration rate of TS and VS was only $11.9 \%$ and $13.2 \%$, respectively. In contrast, $\mathrm{SCOD}, \mathrm{SC}, \mathrm{NH}_{4}{ }^{+}-\mathrm{N}$, and total volatile fatty acids (TVFAs) of all the pretreated sludge's increased with sterilization times. The SCOD concentration for pretreated sludge's is quite similar among $30 \mathrm{~min}, 45 \mathrm{~min}$ and $60 \mathrm{~min}$ sterilization times (Table I). However, SCOD concentration of pretreated sludge $(15 \mathrm{~min})$ was lower than that obtained with the three pretreated sludge's $(30,45$, and $60 \mathrm{~min})$. The highest concentrations of SCOD $(3353 \mathrm{mg} / \mathrm{l})$, $\mathrm{SC}(422 \mathrm{mg} / \mathrm{l}), \mathrm{NH}_{4}{ }^{+}-\mathrm{N}(1001 \mathrm{mg} / \mathrm{l})$, and TVFAs $(1249 \mathrm{mg} / \mathrm{l})$ were obtained for the 60 min pretreated sludge.

TABLE I: The Characteristics of Sewage Sludge Before AND After

\begin{tabular}{|c|c|c|c|c|c|}
\hline \multirow{3}{*}{ Factors } & \multirow{3}{*}{$\begin{array}{l}\text { Untreated } \\
\text { sludge }\end{array}$} & \multicolumn{4}{|c|}{ PRETREATMENT } \\
\hline & & \multicolumn{4}{|c|}{$\begin{array}{l}\text { Pretreated sludge with sterilization treatmen } \\
\text { Pretreatment time (min) }\end{array}$} \\
\hline & & 15 & 30 & 45 & 60 \\
\hline TS (\%) & 2.01 & 1.77 & 1.62 & 1.61 & 1.57 \\
\hline VS (\%) & 1.59 & 1.38 & 1.25 & 1.24 & 1.21 \\
\hline TCOD (mg/l) & 12715 & ND & ND & ND & ND \\
\hline $\mathrm{SCOD}(\mathrm{mg} / \mathrm{l})$ & 1725 & 1828 & 3038 & 3248 & 3353 \\
\hline $\mathrm{TC}(\mathrm{mg} / \mathrm{l})$ & 3341 & 3076 & 2928 & 2829 & 2811 \\
\hline $\mathrm{SC}(\mathrm{mg} / \mathrm{l})$ & 59 & 257 & 341 & 388 & 422 \\
\hline $\mathrm{NH}_{4}{ }^{+}-\mathrm{N}(\mathrm{mg} / \mathrm{l}$ & 1) 780 & 804 & 901 & 992 & 1001 \\
\hline TVFAs (mg/l) & ) 865 & 1004 & 1802 & 2245 & 1980 \\
\hline $\mathrm{pH}$ & 6.4 & 6.4 & 6.4 & 6.4 & 6.4 \\
\hline
\end{tabular}

TS, total solids; VS, volatile solids; TCOD, total chemical oxygen demand; SCOD, soluble chemical oxygen demand; TC, total carbohydrate; SC, Soluble carbohydrate; $\mathrm{NH}_{4}{ }^{+}-\mathrm{N}$, ammonia nitrogen; TVFAs, total volatile fatty acids. ND, not determined. The percentages were calculated on the basis of dry weight.

Table I shows that the main components of SCOD in pretreated sludge are carbohydrates, $\mathrm{NH}_{4}{ }^{+} \mathrm{N}$, and VFAs. This data implies that organic matters in sewage sludge were released from microbial cells, and subsequently these insoluble solid organics are converted into soluble substances [15]. Compared to an initial SCOD concentration of 1725 $\mathrm{mg} / \mathrm{l}$ in untreated sewage sludge, SCOD concentration in pretreated sludge's increased 1.2 to 1.9 -fold with different sterilization times. This is in agreement with the result of Feng [20], who showed a 2.7-fold increase in SCOD concentration from pretreated sludge by ultrasonic treatment. Moreover, there was only a small increase in ammonia amounts from pretreated (autoclave treatment) sludge compared to ammonia concentration in untreated sludge. Feng et al. [21] also reported a small amount of $\mathrm{NH}_{4}^{+}-\mathrm{N}$ increase from the ultrasonic pretreated sludge. It is likely that the nitric organics, such as proteins and nucleic acid, were hardly degraded by heat-shock treatment into smaller soluble molecular components [22].

\section{B. Microorganism Activity}

The microbial quantity and activity can be gauged by the ATP concentration value, a good indicator of metabolically active cells and an index of microbial density in anaerobic fermentation [17], [23]. Hence, the ATP concentration was measured in untreated and pretreated sludge's by sterilization treatment. Theoretically, large numbers (concentration) of microorganisms would contribute to a higher ATP concentration. In reality, ATP concentration of the untreated sludge $(0.579 \mu \mathrm{mol} / \mathrm{l}$ ATP value $)$, was much higher than that of the pretreated sludge's (Fig. 1). Post-sterilization treatment, the ATP concentration sharply decreased. Moreover, in the 60 min pretreated sludge, the ATP value was zero. It can be inferred that not only hydrogen-consuming bacteria (mostly methanogens), but also endospores from microorganisms such as hydrogen-producing bacteria and acid-forming bacteria are effectively suppressed under longer sterilization times [24]. Sterilization treatment of pretreated sludge could also improve anaerobic digestibility due to an increase in the soluble carbon and nitrogen after the pretreatment process [9, $25,26]$. Based on the above result, further experiments from the pretreated sludge as substrate by mixed cultures for hydrogen production were conducted through anaerobic fermentation.

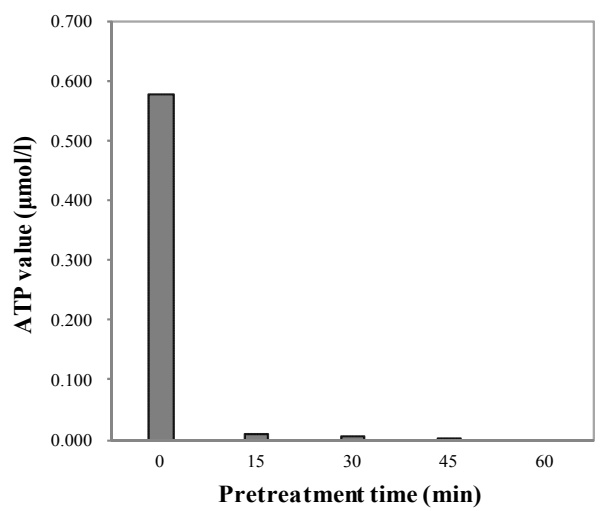

Fig. 1. ATP Values in the untreated sludge and pretreated sludge's by sterilization treatment.

\section{Biogas Production from Untreated or Pretreated Sludge by Mixed Cultures}

Fig. 2 shows the change in accumulated biogas and corresponding biogas contents (hydrogen and methane) in the reactors with untreated sludge or four different kinds of pretreated sludge's by sterilization treatment. Cumulative biogas production during three days from untreated sludge and pretreated sludge's for $15 \mathrm{~min}, 30 \mathrm{~min}, 45 \mathrm{~min}$, and 60 min was $104 \mathrm{ml}, 61 \mathrm{ml}, 78 \mathrm{ml}, 85 \mathrm{ml}$, and $86 \mathrm{ml}$, respectively (Fig. 2a). The control reactor containing mixed cultures without additives did not generate any biogas. Biogas production in the pretreated sludge's significantly increased till $24 \mathrm{~h}$. After $24 \mathrm{hrs}$, biogas production only slightly increased till the end of the experiments (Fig. 2a). This demonstrated that cultivating mixed cultures, which include hydrogen-producing bacteria, could readily use soluble organics (carbon and nitrogen) in the sterilization sludge, resulting in rapid hydrogen generation $[27,28]$. In addition, hydrogen content in the pretreated sludge's was observed between the range of $28.2 \%$ and $60.0 \%$ (Fig. 2b) with no methane detected (Fig. 2c) during the fermentation period. In contrast, biogas production from untreated sludge using mixed cultures increased gradually (Fig. 2a), and the methane 
content increased slightly from $15.9 \%$ to $27.0 \%$ (Fig. 2c) during the fermentation period. However, hydrogen content decreased significantly from a peak at $8 \mathrm{~h}(16.1 \%$ of the biogas) to almost negligible levels after $48 \mathrm{~h}$ (Fig. 2b). A possible reason may lie in the presence of a variety of microorganisms, including hydrogen-consuming bacteria such as methanogens in the untreated sludge [29].
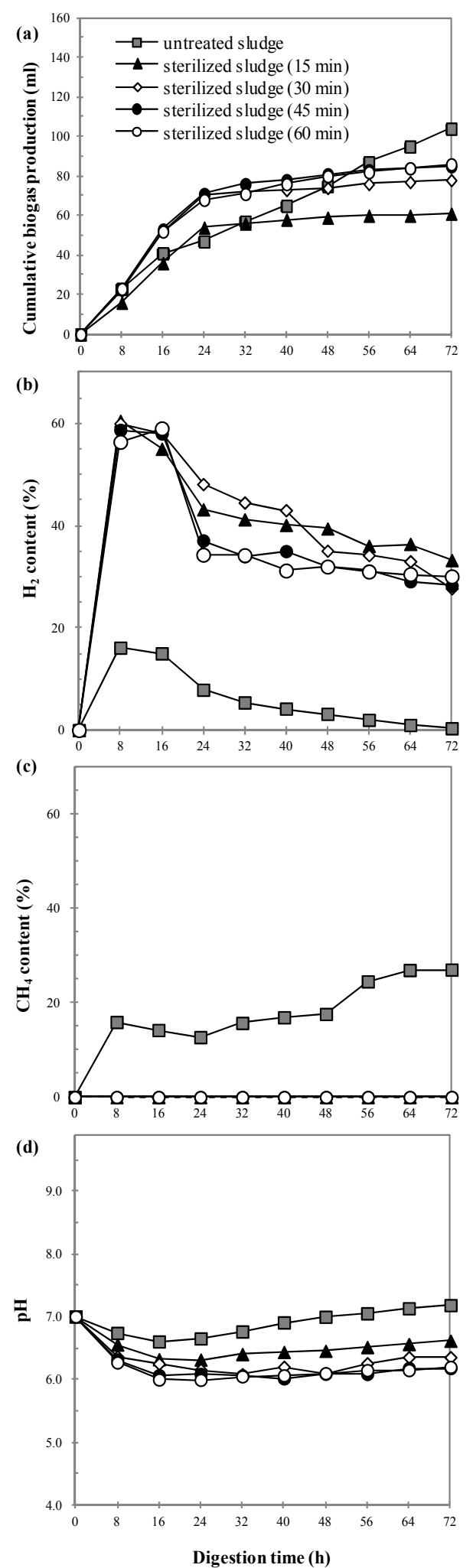

Fig. 2. Cumulative biogas production (a), contents of the $\mathrm{H}_{2}$ (b) and $\mathrm{CH}_{4}$ (c) and daily variations in $\mathrm{pH}(\mathrm{d})$ for the five bioreactors during the fermentation period.

These microorganisms would aid in the consumption of hydrogen along with a generation of methane and carbon dioxide. Nonetheless, pretreatment of sludge via sterilization is a feasible substrate for hydrogen production using mixed anaerobic cultures.

\section{Effect of Untreated or Pretreated Sludge on Fermentative Hydrogen Production}

Hydrogen yield (calculated from equation 1) from the untreated sludge and four different kinds of pretreated sludge's by sterilization treatment is shown in Table II. Hydrogen production from all pretreated sludge's increased with sterilization time. The sewage sludge pretreated at $121^{\circ} \mathrm{C}$ for $60 \mathrm{~min}$ gave highest hydrogen yield $(25.5 \mathrm{ml}$ $\mathrm{H}_{2} / \mathrm{g}$-VS sludge added) during three days. The maximum hydrogen yield on day three from pretreated sludge for 45

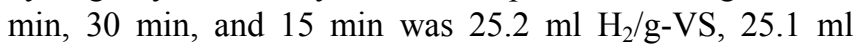
$\mathrm{H}_{2} / \mathrm{g}$-VS, and $16.8 \mathrm{ml} \mathrm{H}_{2} / \mathrm{g}$-VS, respectively. For comparison, untreated sludge as the substrate was investigated in its ability to produce hydrogen. Under this scenario, daily hydrogen production was negligible, and the maximum hydrogen yield obtained was only $3.9 \mathrm{ml} \mathrm{H}_{2} / \mathrm{g}$-VS sludge added on day three. When untreated sludge was used as substrate, hydrogen content decreased on a daily basis (Fig. 2b), while the methane content increased (Fig. 2c) during the fermentation period. This result clearly demonstrated the negative effects of untreated sludge on hydrogen fermentation performance. Consequently, maximum hydrogen yields from the pretreated sludge's for $15 \mathrm{~min}, 30$ $\mathrm{min}, 45 \mathrm{~min}$, and $60 \mathrm{~min}$ was about 4.3 to 6.5 -fold higher than that of the untreated sludge. Kang et al. [30] reported a significant increase in fermentative hydrogen production during the fermentation of pretreated (heat or alkaline) sludge.

TABLE II: HYDROGEN YIELDS FROM THE UNTREATED SLUDGE AND STERILIZED SLUdGE'S AT $121^{\circ} \mathrm{C}$ BY MIXED Cultures

\begin{tabular}{lllllll}
\hline \hline Pretreatment time (min) & 0 & & 15 & 30 & 45 & 60 \\
\cline { 1 - 2 } & $\begin{array}{l}\text { Maximum } \mathrm{H}_{2} \text { yield } \\
\left(\mathrm{ml} \mathrm{H} \mathrm{H}_{2} / \mathrm{g}-\mathrm{VS} \text { sludge added }\right)\end{array}$ & 3.9 & 16.9 & 25.1 & 25.3 & 25.6 \\
\hline \hline
\end{tabular}

Xiao and Liu [15] reported the maximum hydrogen yields of sterilized sludge and raw sludge by anaerobic self-fermentation as $16.26 \mathrm{ml} \mathrm{H}_{2} / \mathrm{g}$-VS and $0.35 \mathrm{ml} \mathrm{H}_{2} / \mathrm{g}$-VS, respectively. Contrastingly, those yields [15] were markedly lower than the results obtained in this study from the pretreated sludge's (16.8-25.5 $\mathrm{ml} \mathrm{H}_{2} / \mathrm{g}$-VS) and untreated sludge (3.9 $\left.\mathrm{ml} \mathrm{H}_{2} / \mathrm{g}-\mathrm{VS}\right)$ using mixed cultures. This phenomenon may be attributed to higher biomass used in cultivation of mixed cultures in this study [31], [32]. As shown in Table II and Table I, the maximum hydrogen yield and solubilization rate for sludge treated for the longest duration $(60 \mathrm{~min}$ ) was almost equal to those of treated sludge for $30 \mathrm{~min}$ and $45 \mathrm{~min}$. These results indicated an optimal condition of $30 \mathrm{~min}$ sterilization pretreatment of sewage sludge for enhanced hydrogen production. Under optimum conditions, the VS of solubilization and anaerobic fermentation process at the end of the batch experiment were reduced by $21.4 \%$ and $20.0 \%$, respectively, relative to the starting content (Fig. 3). This means that total VS removal efficiency was $41.4 \%$, which was 1.5 -fold higher than the value obtained with untreated sludge in anaerobic 
fermentation process, and which can be attributed to the breakdown of organic solids in sludge during the solubilization process.

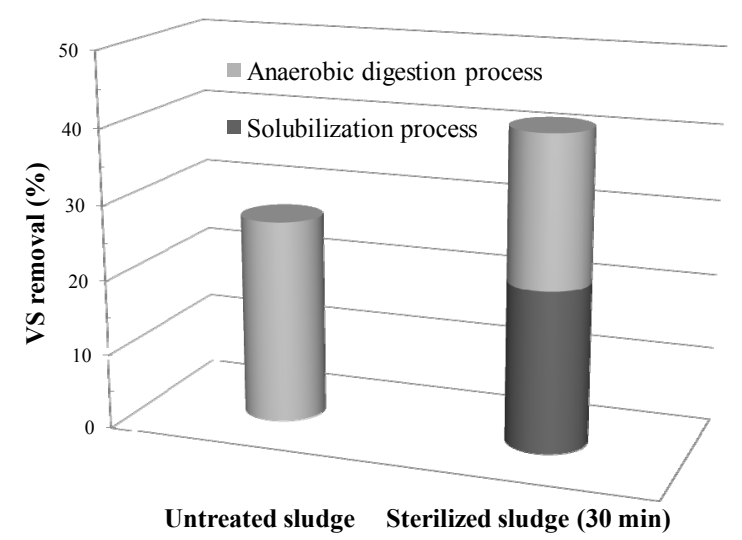

Fig. 3. VS removal efficiency in the untreated sludge and sterilized sludge.

\section{E. Biological Context Evaluation}

The change in $\mathrm{pH}$ is illustrated during the anaerobic fermentation process of untreated or pretreated sludge in Fig. $2 \mathrm{~d}$. In case of untreated sludge, the $\mathrm{pH}$ value first decreased slightly followed by an increase gradually from 7.0 to 7.2. This $\mathrm{pH}$ condition is not suitable for fermentative hydrogen production, but is rather a representative of the best condition for methanogens survival [27]. Indeed, a small amount of hydrogen was produced daily from untreated sludge by mixed culture throughout the experiment (Fig. 2). By contrast, the final $\mathrm{pH}$ value in all bioreactors with pretreated sludge as the substrate was lower than the initial $\mathrm{pH}$ of 7.0. In case of pretreated sludge's by sterilization treatment, the final $\mathrm{pH}$ ranged from 6.2 to 6.6 . In addition, the $\mathrm{pH}$ in pretreated sludge's (30 min, $45 \mathrm{~min}$, and $60 \mathrm{~min}$ ) dropped sharply from the start (7.0) to $16 \mathrm{~h}(6.0-6.2)$, and then remained between 6.0 and 6.4 until end of the batch experiment. One possible reason for this $\mathrm{pH}$ variation tendency may be that the degradation of organic matters like carbohydrates in sludge coincided with the production of VFAs [33]. After $16 \mathrm{hrs,} \mathrm{it}$ is possible that the proteins in sludge were degraded resulting in the release of $\mathrm{NH}_{4}{ }^{+}-\mathrm{N}$ with time. Hence, a slight increase in $\mathrm{pH}$ was seen. The $\mathrm{NH}_{4}{ }^{+}-\mathrm{N}$ can neutralize organic acids produced in the anaerobic process [34].

Table III summarizes obtained soluble substances at end of the batch experiments from the untreated or pretreated sludge (sterilization treatment for $30 \mathrm{~min}$ ) using mixed cultures. The SCOD of untreated sludge and pretreated sludge was 2224 $\mathrm{mg} / \mathrm{l}$ and $3923 \mathrm{mg} / \mathrm{l}$. The SCOD of both the sludge samples increased, and which is due to the hydrolysis of sludge in the anaerobic fermentation process. In the case of pretreated sludge, major SCOD was metabolites (1659 mg/l), $\mathrm{NH}_{4}{ }^{+}-\mathrm{N}$ $(1878 \mathrm{mg} / \mathrm{l})$, and carbohydrates $(284 \mathrm{mg} / \mathrm{l})$. In the case of untreated sludge, the SCOD consisted mainly of $\mathrm{NH}_{4}{ }^{+}-\mathrm{N}$ $(1521 \mathrm{mg} / \mathrm{l})$, metabolites $(548 \mathrm{mg} / \mathrm{l})$, and carbohydrates $(32$ $\mathrm{mg} / \mathrm{l})$. It was proposed that the hardly degradable microbial cell walls in sludge were broken up by sterilization treatment into organic substances. The organic substances were then easily hydrolyzed and/or converted into more SCOD compared to the untreated sludge in anaerobic digestion process, thereby increasing the SCOD concentration [35].

In general, the fermentative hydrogen production is accompanied with production of metabolites, such as VFAs
$[33,36,37]$. Therefore, variation of VFAs in the fermentation process is a useful indicator, especially the butyrate/acetate (B/A) ratio, for monitoring hydrogen production in the thermophilic fermentation process [38]. As shown in Table III, approximately 3 -fold more VFAs were produced with the sterilized sludge $(30 \mathrm{~min})$ in comparison with the untreated sludge. High concentrations of acetate $(33.5 \%)$ and butyrate $(46.2 \%)$ were observed when the $\mathrm{pH}$ was in the range of 6.0-6.3 in the sterilized sludge $(30 \mathrm{~min})$ during the fermentation period (Fig. 2d).

TABLE III: CONCENTRATION OF THE SOLUBLE SUBSTANCES AT THE END OF BATCH EXPERIMENTS

\begin{tabular}{lll}
\hline \hline Factors & Untreated sludge & Sterilized sludge (30 min) \\
\hline Acetate (\%) & 13.9 & 33.5 \\
Propionate (\%) & 86.1 & 20.3 \\
Butyrate (\%) & 0.0 & 46.2 \\
TVFAs (mg/l) & 548 & 1659 \\
$\mathrm{SC}(\mathrm{mg} / \mathrm{l})$ & 32 & 284 \\
$\mathrm{NH}_{4}^{+}-\mathrm{N}(\mathrm{mg} / \mathrm{l})$ & 1521 & 1878 \\
$\mathrm{SCOD}(\mathrm{mg} / \mathrm{l})$ & 2224 & 3923 \\
\hline \hline
\end{tabular}

Results indicate that VFAs accumulate during the fermentation process, and are not converted into methane in all the pretreated sludge's cases (Fig. 2c). This might be a reason for the observed decline in the overall $\mathrm{pH}$ of the sterilized sludge (Fig. 2d). In the case of pretreated sludge (30 $\mathrm{min})$, the $\mathrm{B} / \mathrm{A}$ ratio was approximately 1.4 . This correlates to a higher yield for hydrogen production with higher butyrate content [39]. This result suggests that the pretreated sludge by sterilization treatment using mixed culture might increase hydrogen production via the butyrate and acetate fermentation pathway [38]. Zhu and Béland [40] also reported that butyrate concentration was much higher than acetate concentration from sucrose medium using pretreated digested wastewater sludge by heat-shock, acid, base, and aeration for producing hydrogen. On the other hand, a higher concentration of propionate $(86.1 \%)$ along with relatively lower concentration of acetate $(13.9 \%)$ and lack of butyrate were observed in $\mathrm{pH}$ range of 7.0-7.2 in the untreated sludge throughout the experiment (Table III). This could be due to the utilization of VFAs for biogas production (mostly carbon dioxide and methane) resulting in the lower VFAs value along with higher $\mathrm{NH}_{4}{ }^{+}-\mathrm{N}$ concentration and a simultaneous increase in $\mathrm{pH}$ (Fig. 2d), thereby causing the overall hydrogen production to decline. This resulted in an increase in the $\mathrm{pH}$, and finally to digester failure. As a result, the change in $\mathrm{pH}$ and SCOD including VFAs and $\mathrm{NH}_{4}{ }^{+}-\mathrm{N}$ during the fermentation period are very important factors for efficient hydrogen production under anaerobic thermophilic conditions.

\section{ACKNOWLEDGMENT}

Authors greatly appreciate Dr. Dong-Yeol Lee (Environmental Technology Team of the GS Engineering \& Construction Co. Ltd.) for a critical reading of the paper and constructive comments therein.

\section{REFERENCES}

[1] C. Sreela-or, P. Plangklang, T. Imai and A. Reungsang, "Co-digestion of food waste and sludge for hydrogen production by anaerobic mixed cultures: Statistical key factors optimization," International Journal of 
Hydrogen Energy, vol. 36, pp. 14227-37, Oct. 2011.

[2] U. Tezel, M. Tandukar, and S. G. Pavlostathis, "6.35 - Anaerobic Biotreatment of Municipal Sewage Sludge," Comprehensive Biotechnology (Second Edition), Burlington, 2011, pp. 447-61.

[3] J. Massanet-Nicolau, R. Dinsdale and A. Guwy, "Hydrogen production from sewage sludge using mixed microflora inoculum: Effect of $\mathrm{pH}$ and enzymatic pretreatment," Bioresource Technology, vol. 99, pp. 6325-31, Sep. 2008.

[4] H. Yoshida, H. Tokumoto, K. Ishii and R. Ishii, "Efficient, high-speed methane fermentation for sewage sludge using subcritical water hydrolysis as pretreatment," Bioresource Technology, vol. 100, pp. 2933-9, June 2009.

[5] H. Li, C. Li, W. Liu and S. Zou, "Optimized alkaline pretreatment of sludge before anaerobic digestion," Bioresource Technology, vol. 123, pp. 189-94, Nov. 2012.

[6] D. C. Devlin, S. R. R. Esteves, R. M. Dinsdale and A. J. Guwy, "The effect of acid pretreatment on the anaerobic digestion and dewatering of waste activated sludge," Bioresource Technology, vol. 102, pp. 4076-82, Mar. 2011.

[7] Y. Chi, Y. Li, X. Fei, S. Wang and H. Yuan, "Enhancement of thermophilic anaerobic digestion of thickened waste activated sludge by combined microwave and alkaline pretreatment," Journal of Environmental Sciences, vol. 23, pp. 1257-65, Aug. 2011.

[8] M. Climent, I. Ferrer, M. d. M. Baeza, A. Artola, F. Vázquez and X. Font, "Effects of thermal and mechanical pretreatments of secondary sludge on biogas production under thermophilic conditions," Chemical Engineering Journal, vol. 133, pp. 335-42, Sep. 2007.

[9] S. Pilli, P. Bhunia, S. Yan, R. J. LeBlanc, R. D. Tyagi and R. Y. Surampalli, "Ultrasonic pretreatment of sludge: A review," Ultrasonics Sonochemistry, vol. 18, pp. 1-18, Jan. 2011.

[10] I. Toreci, K. J. Kennedy and R. L. Droste, "Evaluation of continuous mesophilic anaerobic sludge digestion after high temperature microwave pretreatment," Water Research, vol. 43, pp. 1273-84, Mar 2009.

[11] C. Eskicioglu, K. J. Kennedy and R. L. Droste, "Enhanced disinfection and methane production from sewage sludge by microwave irradiation," Desalination, vol. 248, pp. 279-85, Nov. 2009.

[12] J.-J. Lay, Y.-J. Lee and T. Noike, "Feasibility of biological hydrogen production from organic fraction of municipal solid waste," Water Research, vol. 33, pp. 2579-86, Aug. 1999.

[13] Y. Li, S. Y. Park and J. Zhu, "Solid-state anaerobic digestion for methane production from organic waste," Renewable and Sustainable Energy Reviews, vol. 15, pp. 821-6, Jan. 2011.

[14] D.-H. Kim, S.-H. Kim, H.-W. Kim, M.-S. Kim and H.-S. Shin, "Sewage sludge addition to food waste synergistically enhances hydrogen fermentation performance," Bioresource Technology, vol. 102, pp. 8501-6, Sep. 2011.

[15] B. Xiao and J. Liu, "Biological hydrogen production from sterilized sewage sludge by anaerobic self-fermentation," Journal of Hazardous Materials, vol. 168, pp. 163-7, Aug. 2009.

[16] D.-Y. Lee, Y.-Y. Li and T. Noike, "Continuous $\mathrm{H}_{2}$ production by anaerobic mixed microflora in membrane bioreactor," Bioresource Technology, vol. 100, pp. 690-5, Jan. 2009.

[17] M. Kim, Y. Yang, M. S. Morikawa-Sakura, Q. Wang, M. V. Lee, D.-Y. Lee, C. Feng, Y. Zhou and Z. Zhang, "Hydrogen production by anaerobic co-digestion of rice straw and sewage sludge," International Journal of Hydrogen Energy, vol. 37, pp. 3142-9, Feb. 2012.

[18] Standard Methods for the Examination of Water and Wastewater, 20th ed. J, Washington, DC: American Public Health Association/American Water Works Association/Water Environment Federation, 1999.

[19] M. Dubois, K. Gilies, J. K. Hammilton, P. A. Robers, and F. A. Smith, "A colorimetric method for the determination of sugars related substances," Analytical Chemistry, vol. 28, pp. 350-6, Mar. 1951.

[20] W. Feng, "The effect of ultrasonic treatment on biological hydrogen production from anaerobic fermentation of sludge," Journal of Biotechnology, vol. 136, Supplement p. S646, Oct. 2008.

[21] X. Feng, H. Lei, J. Deng, Q. Yu and H. Li, "Physical and chemical characteristics of waste activated sludge treated ultrasonically," Chemical Engineering and Processing: Process Intensification, vol. 48, pp. 187-94, Jan. 2009.

[22] R. Tan, K. Miyanaga, D. Uy and Y. Tanji, "Effect of heat-alkaline treatment as a pretreatment method on volatile fatty acid production and protein degradation in excess sludge, pure proteins and pure cultures," Bioresource Technology, vol. 118, pp. 390-8, Aug. 2012.

[23] C. P. Chu, D. J. Lee, B.-V. Chang, C. H. You, C. S. Liao and J. H. Tay, "Anaerobic digestion of polyelectrolyte flocculated waste activated sludge," Chemosphere, vol. 53, pp. 757-64, Nov. 2003.

[24] J. Wang and W. Wan, "Comparison of different pretreatment methods for enriching hydrogen-producing bacteria from digested sludge,"
International Journal of Hydrogen Energy, vol. 33, pp. 2934-41, June 2008.

[25] H. Carrère, C. Dumas, A. Battimelli, D. J. Batstone, J. P. Delgenès, J. P. Steyer and I. Ferrer, "Pretreatment methods to improve sludge anaerobic degradability: A review," Journal of Hazardous Materials, vol. 183, pp. 1-15, Nov. 2010.

[26] Y. Yan, H. Chen, W. Xu, Q. He and Q. Zhou, "Enhancement of biochemical methane potential from excess sludge with low organic content by mild thermal pretreatment," Biochemical Engineering Journal, vol. 70, pp. 127-34, Jan. 2012.

[27] C.-f. Liu, X.-z. Yuan, G.-m. Zeng, W.-w. Li and J. Li, "Prediction of methane yield at optimum $\mathrm{pH}$ for anaerobic digestion of organic fraction of municipal solid waste," Bioresource Technology, vol. 99, pp. 882-8, Mar. 2008.

[28] C. Liu, Y. Yang, Q. Wang, M. Kim, Q. Zhu, D. Li and Z. Zhang, "Photocatalytic degradation of waste activated sludge using a circulating bed photocatalytic reactor for improving biohydrogen production," Bioresource Technology, vol. pp. 30-6, Dec. 125, 2012.

[29] L. R. Vasconcelos de Sá, T. Corrêa de Oliveira, T. Ferreira dos Santos, A. Matos, M. C. Cammarota, E. M. Morais Oliveira and V. S. Ferreira-Leitão, "Hydrogenase activity monitoring in the fermentative hydrogen production using heat pretreated sludge: A useful approach to evaluate bacterial communities performance," International Journal of Hydrogen Energy, vol. 36, pp. 7543-9, Jul. 2011.

[30] J.-h. Kang, D. Kim and T.-j. Lee, "Hydrogen production and microbial diversity in sewage sludge fermentation preceded by heat and alkaline treatment," Bioresource Technology, vol. pp. 239-43, Apr. 109, 2012.

[31] C.-Y. Lin and W.-C. Hung, "Enhancement of fermentative hydrogen/ethanol production from cellulose using mixed anaerobic cultures," International Journal of Hydrogen Energy, vol. 33, pp. 3660-7, Jul. 2008.

[32] J. Wang and W. Wan, "Effect of temperature on fermentative hydrogen production by mixed cultures," International Journal of Hydrogen Energy, vol. 33, pp. 5392-7, Oct. 2008.

[33] L. Appels, J. Baeyens, J. Degrève and R. Dewil, "Principles and potential of the anaerobic digestion of waste-activated sludge," Progress in Energy and Combustion Science, vol. 34, pp. 755-81, Dec. 2008.

[34] S. Venkata Mohan, V. Lalit Babu and P. N. Sarma, "Effect of various pretreatment methods on anaerobic mixed microflora to enhance biohydrogen production utilizing dairy wastewater as substrate," Bioresource Technology, vol. 99, pp. 59-67, Jan. 2008.

[35] L. Guo, X.-M. Li, X. Bo, Q. Yang, G.-M. Zeng, D.-x. Liao and J.-J. Liu, "Impacts of sterilization, microwave and ultrasonication pretreatment on hydrogen producing using waste sludge," Bioresource Technology, vol. 99, pp. 3651-8, June 2008.

[36] C. Y. Lin and C. H. Lay, "Carbon/nitrogen-ratio effect on fermentative hydrogen production by mixed microflora," International Journal of Hydrogen Energy, vol. 29, pp. 41-5, Jan. 2004.

[37] M. Kim, C. Liu, J.-W. Noh, Y. Yang, S. Oh, K. Shimizu, D.-Y. Lee and Z. Zhang, "Hydrogen and methane production from untreated rice straw and raw sewage sludge under thermophilic anaerobic conditions," International Journal of Hydrogen Energy, vol. 38 pp. 8648-56, Jul. 2013.

[38] D.-Y. Lee, Y. Ebie, K.-Q. Xu, Y.-Y. Li and Y. Inamori, "Continuous $\mathrm{H}_{2}$ and $\mathrm{CH}_{4}$ production from high-solid food waste in the two-stage thermophilic fermentation process with the recirculation of digester sludge," Bioresource Technology, vol. 101, Supplement, pp. S42-S7, Jan. 2010.

[39] Q.-B. Zhao and H.-Q. Yu, "Fermentative $\mathrm{H}_{2}$ production in an upflow anaerobic sludge blanket reactor at various $\mathrm{pH}$ values," Bioresource Technology, vol. 99, pp. 1353-8, Mar. 2008.

[40] H. Zhu and M. Béland, "Evaluation of alternative methods of preparing hydrogen producing seeds from digested wastewater sludge," International Journal of Hydrogen Energy, vol. 31, pp. 1980-8, Nov. 2006.

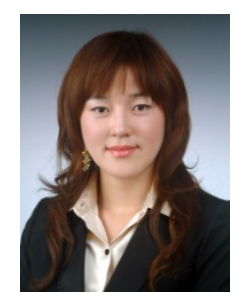

Mijung Kim was born on February 18, 1981 in South Korea. She received her B.Sc degree at the Gachon University (Korea) in 2006, and M.Sc. and Ph.D. degrees at the University of Tsukuba (Japan) in 2010 and 2013, respectively. She majored in Agricultural Science and her thesis for doctor's degree was entitled "Bioenergy conversion efficiency in a two-stage $\mathrm{H}_{2} / \mathrm{CH}_{4}$ fermentation process using organic waste". Her main research interests are Sustainable development, Renewable energy, Waste management, Wastewater treatment, Environmental science, Obesity, and Cell culture. Currently, she is 
Postdoctoral Researcher at Biomedical Research Institute, National Institute of Advanced Industrial Science and Technology (AIST), Japan.

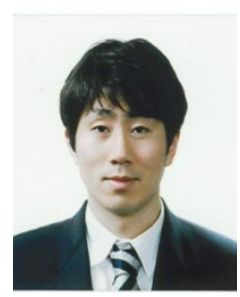

Sechang Oh was born on February 18, 1979 in Republic of Korea. He received his B.Sc. degree at the Chung-Ang University (Korea) in 2005 and M.Sc. degrees at the University of Chung-Ang and University of Tsukuba (Japan) in 2007 and 2011, respectively. His main research interests are Obesity, Liver disease, Lifestyle modification, Human health, Diet, Exercise, and Renewable energy. Currently, he is pursuing the doctoral degree in Sports Medicine, at the Graduate School of Comprehensive Human Sciences, University of Tsukuba, Japan.

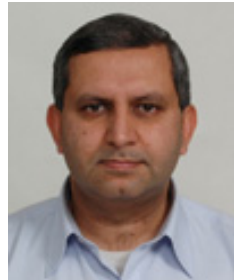

Randeep Rakwal was born on 2nd November, 1968 in Delhi, India. Obtaining B.Sc. (Hons) degree in Botany from Delhi University, he did M.Sc (1992) in Plant Pathology from G.B. Pant University of Agriculture \& Technology (India), followed by Ph.D. (Monbusho Scholarship) in Biochemistry and Biotechnology from Tokyo University of Agriculture and Technology (Japan) in 1997. He worked at various National Institutes in Tsukuba Science City in Agriculture, Environment, and Health Technology. Currently, he is Professor at Organization for Educational Initiatives, University of Tsukuba (Japan) and helps manage Graduate General Education Courses program. He is also Visiting Professor at Showa University School of Medicine (Tokyo, Japan). He is also one of the initiators of International Plant Proteomics Organization. Major current interests are utilizing omics technologies, especially transcriptomics and proteomics, in plant (mostly rice) and mammalian systems to answer biological questions, with special interest in jasmonic acid, ozone, pathogen and radiation, and brain and $\mathrm{DOHaD}$.

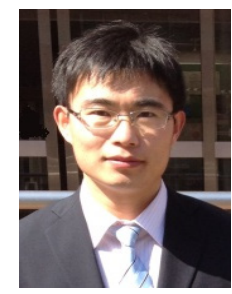

Chungaung Liu was born in January 1985 in the Shandong province, China. He got the Master's degree in Agriculture Engineering from the China Agricultural University (Beijing, China) and is currently studying for his Ph.D. degree in Environmental Science at the Graduate School of Life and Environmental Sciences, University of Tsukuba (Japan). His major interests are Wastewater treatment, Bio-energy, and Photocatalysis.

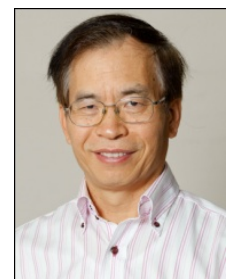

Zhenya Zhang was born on May 1, 1957 in China $\mathrm{He}$ received his B.Sc. degree at the Hebei University of Technology (China) in 1982, and M.Sc. (Environmental Science) and Ph.D. (Agriculture Science) degrees at the University of Tsukuba (Japan) in 1992 and 1995, respectively. He worked at the Tianjin City Government as a public employee. He was dispatched to Japan as Agriculture Technology Trainee at Ministry of International Machinery Industry. Currently, he is Professor at Graduate School of Life and Environmental Sciences, University of Tsukuba (Japan). Major curren interests are application of Biotechnology and Life Sciences on practical use for a Sustainable Society, including the basic and applied research on Clean energy, Biomass transformation, Water purification and Functional food. 